\title{
Seasonal zooplankton patterns in a shallow oligotrophic lake : Loch Rusky (Scotland)
}

\author{
S. Romol
}

Keywords : Zooplankton, seasonal succession, lake, Scotland.

The zooplankton taxa and their seasonal distribution are describeb for Loch Rusky, a shallow oligotrophic lake in the central region of Scotland. 15 species were indentified : 11 Rotifera, 2 Cladocera and 2 Copepoda. Only 5 species Polyarthra remata, Keratella cochlearis, Filinia terminalis, Trichocerca sp. and Eudiaptomus gracilis occurred in sufficient numbers to facilitate a description of their seasonal pattern. The annual zooplankton variation was dominated by rotifers for most of the year, but copepods ( $E$. gracilis, Cyclops sp.) only were dominant in the epilimnion during summer. It is presumed that this pattern was the result of the rotifers faster rate of reproduction and higher grazing efficiency under oligotrophic conditions, as well as the decrease of larger zooplankton by the continuous programme of fish stocking in the lake.

Evolution saisonnière du zooplancton dans le lac Rusky (Ecosse)

Mots clés : Zooplancton, succession saisonnière, lac, Ecosse.

La composition et l'évolution annuelle du zooplancton ont été étudiées dans le Loch Rusky, un petit lac oligotrophe de l'Ecosse centrale. 15 espèces ont été identifiées : 11 Rotifères, 2 Cladocères et 2 Copépodes. 5 espèces seulement Polyarthra remata, Keratella cochlearis, Filinia terminalis, Trichocerca sp. et Eudiaptomus gracilis sont apparues en nombre suffisant pour décrire leur évolution saisonnière.

Les Rotifères sont dominants durant la majeure partie de l'année tandis que les Copépodes $E$. gracilis, Cyclops sp. dominent seulement dans l'épilimnion en été. Le taux de reproduction plus rapide des Rotifères, leur plus grande efficacité de broutage dans des conditions oligotrophes et la diminution du grand zooplancton consécutive au programme suivi d'alevinage du lac conditionnent probablement ce schéma.

\section{Introduction}

The plankton of small lakes has been hitherto poorly documented, especially in Scotland (May 1983), where recent research has been focussed on the characteristic larger lakes of this region (Maitland 1981). Nevertheless, the increasing interest in the study of small water bodies makes the gathering of information in this latitude more important for further comparative studies on zooplankton distribution. The present study includes a taxonomic list of species and the annual zooplankton pattern described in Loch Rusky, a shallow oligotrophic lake in Scotland (Maulood 1974, Romo 1987).

1. Departamento de Ecologia, Facultat de Biologia, Universidad de Valencia, 46100 Burjasot, Valencia, España.

\section{Study area, material and methods}

Loch Rusky lies in the central part of Scotland (National Grid Reference NN615035), just to the south of the Highland Boundary Fault. The surface area of the lake is about $0.2 \mathrm{~km}^{2}$, with a maximum length of roughly $800 \mathrm{~m}$ and mean width of $400 \mathrm{~m}$. It has a maximum depth of $15 \mathrm{~m} .86 \%$ of the catchment area (about $3 \mathrm{~km}^{2}$ ) is covered with softwood forestry plantations and the rest by moorland.

The observations covered the period October 1985 to September 1986. One sampling point was situated in the northern part of lake, in a site of the maximum depth. Sampling was carried out fortnightly, except between December to February where sampling was monthly. Water samples were taken with a 6 litres Van Dorn bot tle at five depths : 
surface, 1, 3, 5 and $10 \mathrm{~m}$. Zooplankton subsamples were sedimented and counted using inverted microscope (Edmonson \& Winberg 1971). Temperature and oxygen were measured in the field using a Mackereth Mark II temperature/oxygen probe.

\section{Results}

\subsection{Temperature and Oxygen}

The lake was seen to ne monomictic with only an annual stratification period occurring in summer, from June to August (fig. 1). During this period, the hypolimnion with a more or less constant temperature of $11^{\circ} \mathrm{C}$ was only well defined in the depth $9 \mathrm{~m}$. The epilimnion was comprised in the top $6 \mathrm{~m}$ and extended deeper during the summer. The maximum temperature of $20^{\circ} \mathrm{C}$ was reached in July in the top $2 \mathbf{~ m}$. Isothermal conditions prevailed during the remaining year, with a thermal range between 3.5 to $13^{\circ} \mathrm{C}$. Icecover was not observed on any sampling date but it is probable that occasional surface freezing occured during winter. Oxygen had similar seasonal and vertical distribution to temperature. Saturated oxygen levels (135-90\% saturation) remained throughout the whole year and only during summer stagnation did the oxygen fall to $21 \%$ in the hypolimnion.

\subsection{Zooplankton}

A total of 15 species were identified from the zooplankton (Table I), but only five species occurred in sufficient numbers to permit the description of the seasonal pattern.

\section{- Rotifera}

The Rotifers were the most common and abundant species represented in the zooplankton (fig. 2). The maximum biomass was the spring phytoplankton increase (mainly represented by small diatoms). The dominance of Rotifera remained throughout the year except in summer, where Copepoda became dominant in the epilimnion.

Polyarthra remata Skorikov (fig. 3) was the most frequent (84\% occurence) and represented up to $20 \%$ of the total zooplankton biomass (Table I). The seasonal pattern showed three distinct peaks : the first occurred between April and June with values up to $40 \mathrm{ind} / 1$; the second attained the

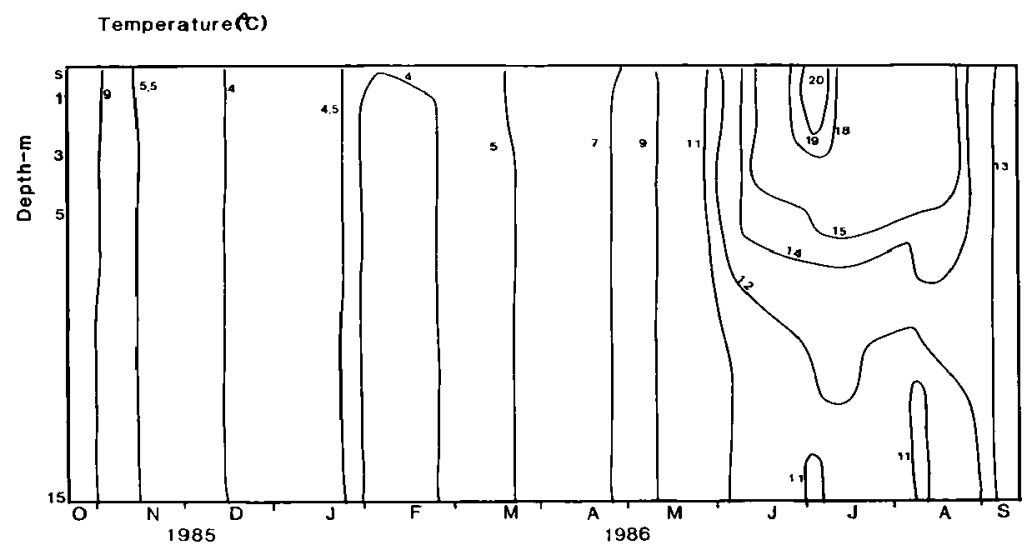

Fig. 1. Isopleths of water temperature from October 1985 to September 1986 , expressed in degree centigrade. 
Table 1. Occurrence and relative abundance of the zooplankton species in Loch Rusky, during the period October 1985 to September 1986.

\begin{tabular}{|c|c|c|}
\hline & OCCURENCE & REL. ABUNDANCE \\
\hline \multicolumn{3}{|l|}{ CLADOCERA } \\
\hline $\begin{array}{l}\text { Daphmia hyalina Leydig } \\
\text { Daphnia longispina Muller }\end{array}$ & \pm & $\ddot{-}$ \\
\hline \multicolumn{3}{|l|}{ ROTIFERA } \\
\hline $\begin{array}{l}\text { Ascomorpha ecaudis Perty } \\
\text { Asplanchna priodonta Gosse } \\
\text { Brachionus angtularis Gosse } \\
\text { Euchlanis dilatata Ehrb } \\
\text { Filinia terminalis Plate } \\
\text { Kellicottia longispina Keilicott } \\
\text { Keratella cochlearis Gosse } \\
\text { Keratella quadrata Muller } \\
\text { Polyarthra remata Skorikov } \\
\text { Trichocerca similis Wierzejski } \\
\text { Trichocerca spp. }\end{array}$ & $\begin{array}{c}- \\
- \\
- \\
- \\
++ \\
+ \\
++ \\
- \\
++ \\
+ \\
+\end{array}$ & $\begin{array}{l}\cdots \\
. \\
. \\
. \\
. \\
. \\
. \\
\cdots \\
- \\
\cdots\end{array}$ \\
\hline \multicolumn{3}{|l|}{ COPEPODA } \\
\hline $\begin{array}{l}\text { Cyclops sp. } \\
\text { Etudiaptomus gracilis } \\
\text { Nauplius }\end{array}$ & $\begin{array}{c}- \\
++ \\
+++\end{array}$ & $\begin{array}{l}. \\
. . \\
\cdots\end{array}$ \\
\hline CILIATES & $+t+$ & . \\
\hline
\end{tabular}

Occurence :

$\begin{array}{rr}100-75 \% & +++ \\ 75-50 \% & ++ \\ 50-25 \% & + \\ <25 \% & -\end{array}$

Rel. Abundance :

$$
\begin{array}{rr}
25-10 \% & \ldots \\
10-5 \% & . . \\
5-1 \% & - \\
<1 \% & -
\end{array}
$$

maximum population levels (about 50 ind/1) during August and September ; and thereafter population numbers decreased to $25 \mathrm{ind} / \mathrm{l}$ in the peak of autumn and remained stable at about $10 \mathrm{ind} / \mathrm{l}$ in winter. The vertical distribution was more or less uniform during the periods of water mixing but at the starting of stratification in June, $P$. remata tended to concentrated behind the thermocline and in July only occurred at $10 \mathrm{~m}$. This distribution was reversed in late summer, where it was restricted to the upper $3 \mathrm{~m}$ of the epilimnion.

Keratella cochlearis Gosse (fig. 3) showed lower occurence $(72 \%)$ and abundance $(9 \%)$ than
$P$. remata. Similar seasonal pattern with less pronounced peaks than those described for $\boldsymbol{P}$. remata was observed for this species under water mixing conditions. During water stagnation $K$. cochlearis showed different vertical distribution in time and space than $P$. ramata, reaching maximun population numbers of $40 \mathrm{ind} / \mathrm{l}$ in July at the thermocline level. Uniform vertical distribution was the pattern during the rest of the other seasons.

Filinia terminalis Plate (fig. 3) had an occurence of $53 \%$ and $6 \%$ of relative frequency. During summer months it was only present in the hypolimnion. Uniform profiles were observed for the rest of 
year, although slightly higher population values were always present at $10 \mathrm{~m}$.

Trichocerca sp (fig. 3) was an occasional species in the zooplankton distinguished by a rapid development (108 ind $/ \mathbf{l})$ in the middle waters during May and July.

\section{- COPEPODA}

It was mainly represented by Eudiaptomus gracilis Sars. Cyclops sp. only appear in low numbers when $E$. gracilis was absent at the beginning of August.

Eudiaptomus gracilis (fig. 4) showed two seasonal population peaks from April to September, both registered in the upper waters. The latter summer increase represented the maximum population numbers of $50 \mathrm{ind} / \mathrm{l}$. Naupliar populations showed two seasonal increases prior to or coinciding with, those observed for adults. The first peak was mainly achieved in the upper $3 \mathrm{~m}$ while the second one in summer was evenly distributed throughout the depths. Similarly low populations $(10 \mathrm{ind} / \mathrm{l})$ in both $E$. gracilis and nauplii remained during autumn-winter.

- ClADOCERA were numerically rare, mainly represented by Daphnia hyalina Leybig in the epilimnion in July.

- Ciliates were not identified in this study and their biomass was bulked together. The occurence was high but was gathered with a low abundance during summer and November.

\section{Discussion}

The rotifers seasonal pattern in Loch Rusky was similar to that shown by the phytoplankton (Romo 1989). The faster rate of reproduction of rotifera over all temperature ranges and higher grazing effeciency under the oligotrophic conditions (Allan 1976) prevailing in the lake, would enable to this group to respond quickly to increasing phytoplankton biomass (mainly represented by nannoplanktonic species). It would also contribute to the dominance of this group for most of the year. The three

Fig. 2. Seasonal and vertical changes of the major zooplankton groups in Loch Rusky, from October 1985 to September 1986. pop./1
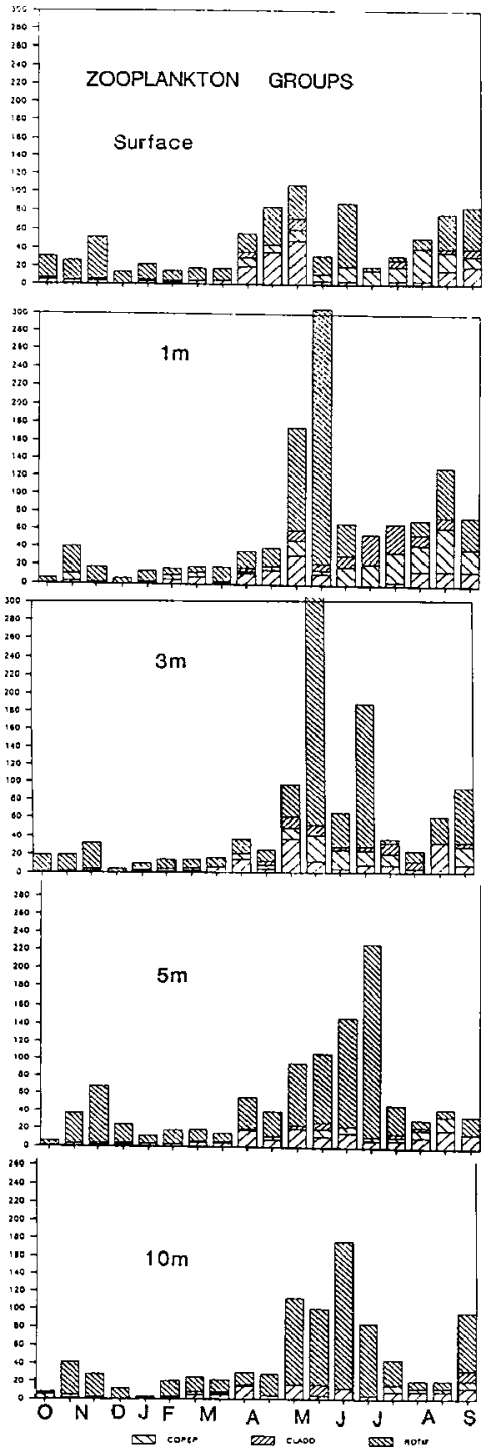
pop./1

Filinia terminalis -

Tricocerca sp. -.-
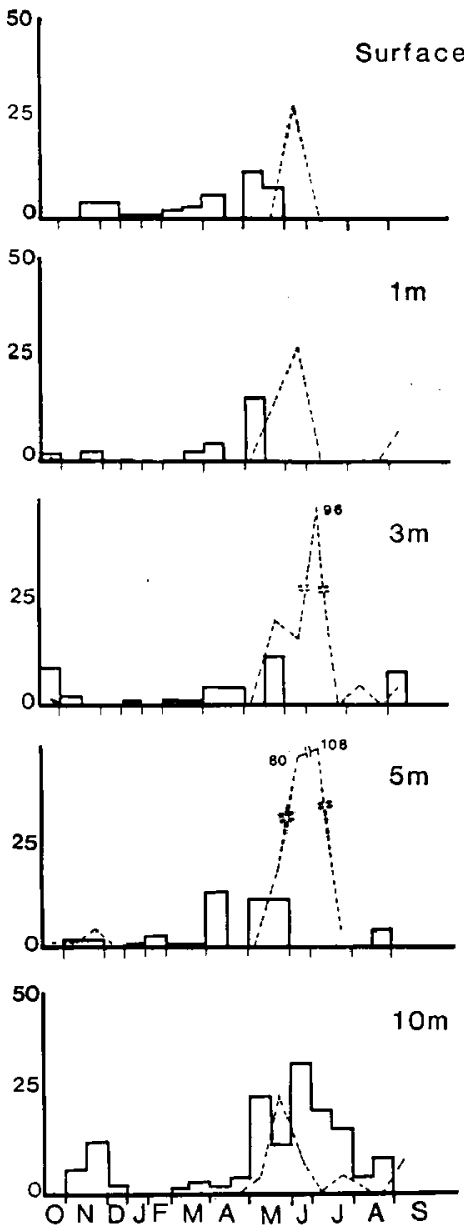

1985 1986
Polyarthra remata -

Keratella cochlearis ...
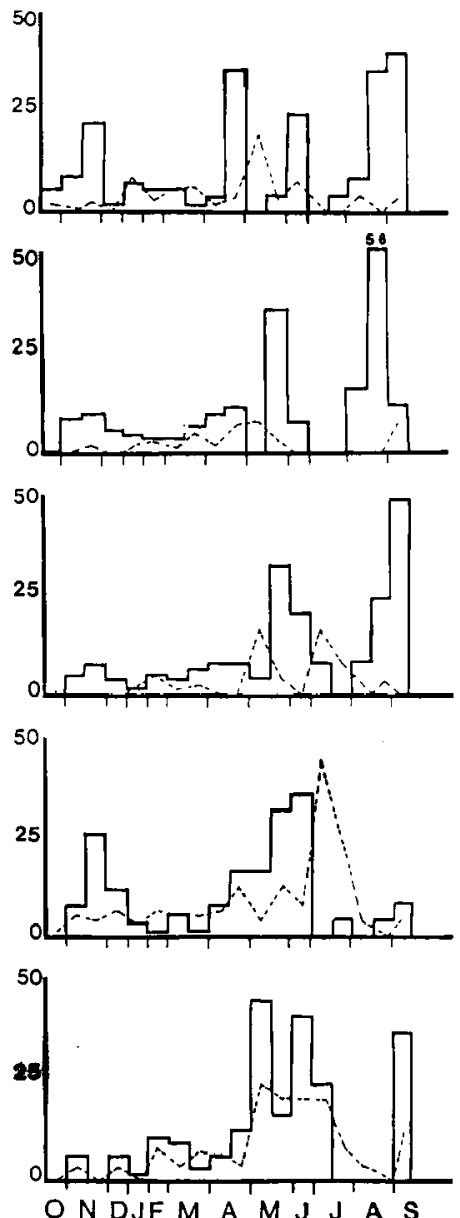

1985

1986

Fig. 3. Depth-time distribution of the rotifers Polyarthra remata Shor., Filinia terminalis Plate, Keratella cochlearis Goss. and Trichocerca sp. in the zooplankton of Loch Rusky during 1985-86, expressed as number of individuals per litre. 

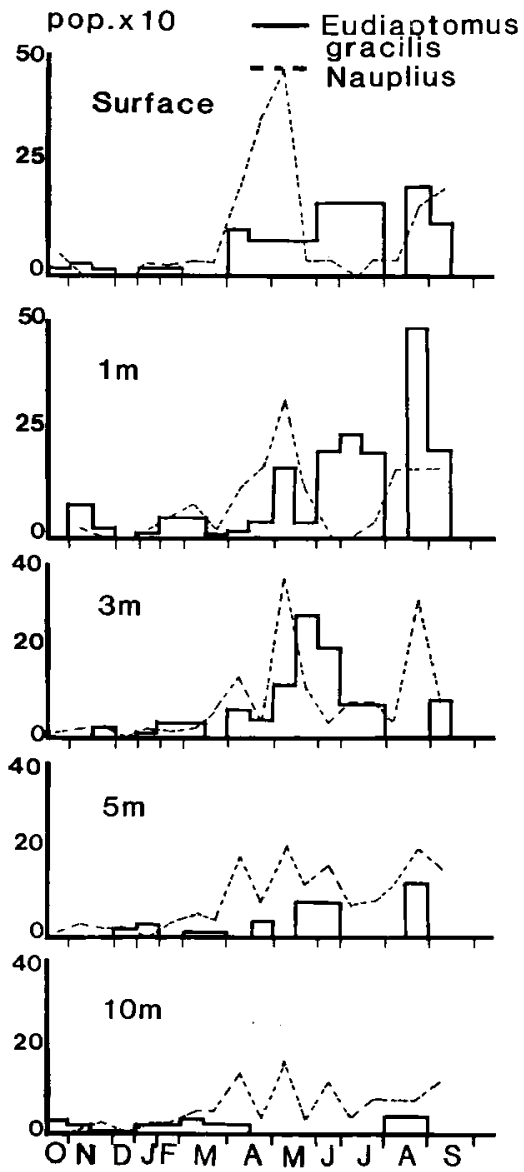

1985

1986

Fig. 4. Depth-time distribution of nauplius and Eudiaptomus gracilis Sars, in Loch Rusky, expressed as number of individuals per litre. main identified rotifer species ( $P$, remala, $K$. cochlearis and $F$. terminalis) co-occurred in the lake for the whole study period. E. terminalis had preference to bottom waters, which agrees with the general niche characteristics described for this species (Ruttner-Kolisko 1974), $P$. remata and $K$. cochlearis overlap time and depth presence during the water mixing seasons but showed segregation in depth at the time of water stratification. It is possible that competition with Daphnia (Neill 1984) and intraspecific niche partitioning under stratified maters (Makarewicz and Likens 1975) conditioned this pattern.

The continuous programme of fish stocking in the lake (rainbow trout, Salmo gairdneri), could strongly influence the abundance of Cladocera (mostly represented by $D$. hyalina) due to feeding relations described for both species in small lakes (Stenson 1972) favouring rotifer dominance.

The long cycle of reproduction of Eudiaptomus gracilis, determined a single season of abundance in the zooplankton in summer. There was coexistence in time and depth between this copepod and $P$. remata (Neill 1984) in late summer and with $D$. hyalina Lampert \& Muck 1985) in July. It seems plausible that niche differenciation and nonequilibrium mechanisms were critical to interactions between these species.

It is likely that temperature and other environmental variables could also influence zooplankton succession by affecting feeding rates and metabolic demands (Hebert 1978).

Loch Rusky showed in general a zooplankton community similar in species composition to that described in the small oligotrophic lakes of Pyrenees (Miracle 1978) and in oligotrophic temperate lakes (Margalef 1983).

\section{References}

Allan (J.D.). 1976. - Life history patterns in zooplankton. Amer. Naturatist $110: 165-180$.

Edmonson (W.T.) \& Winberg (G.G.). 1971. - A manual of methods for the assessment of secondary productivity in fresh. water. IBP Handbook $\mathrm{n}^{\circ} 17,358 \mathrm{p}$.

Hebert (P.D.N.). 1978. - The population biology of Daphnia. Biological Reviews 53 : 387-426.

Lampert (W.) \& Muck (P.). 1985. - Multiple aspects of food limitation in zooplankton communities: The Daphnia. Eudiaptomus example. Archiv für Hydrobiol. 21 : $311-322$. 
Maitland (P.). 1981. - The ecology of the Scotland largest lochs. Lomond, Awe, Ness, Morar and Shiel. Monographiae Biologicae, Vol. 44. Dr. W. Junk Publishers, The Hague Boston London. 297 p.

Makarewicz (J.C.) \& Likens (G.E.). 1975. - Niche analysis of a zooplankton community. Science $190: 100-103$.

May (L.). 1983. - Rotifer occurence in relation to water temperature in Loch Leven, Scotland. Hydrobiologia 104 : 311-315.

Neill (W.E.). 1984. - Regulation of rotifer densities by crustacean zooplankton in a oligotrophic montane lake in British Columbia. Oecologia 61 : 175-181.

Margalef (R.). 1983. - Limmologia. Ed. Omega. Barcelona. $1010 \mathrm{p}$.

Maulood (B.). 1974. - PhD Thesis : Studies on the phytoplankton of Loch Lomond and of Neighbouring Lochs North and South of the Highland Boundary Fauh. Glasgow University. 249 p.
Miracle (M.R.). 1978. - Composición especifica de las comunidades zooplanctónicas de 153 lagos de los Pirineos y su interés biogeográfico. Oecologia aquatica (Barcelona), 3 : 167-191.

Romo (S.) 1987. - MSc. Thesis: The ornual cycle of nutrients and phytoplankton dynamics in shallow monomictic lake in Scotland (Loch Rusky). Glasgow University. 133 p.

Romo (S.). 1989. - Estudio del fitoplancton de un lago somero y oligotrófico : Loch Rusky (Escocia). An. Jard. Bot. Madrid. Tomo 46-I : 127-138.

Ruttner-Kolisko (A.). 1974. - Plankion Rotifers. Biology and taxonomy. Die Biennengewässer. Vol. XXVI part I.

Stenson (J.A.), 1972. - Fish predation effects on the species composition of the zooplankton community in eight small forest lakes. Rep. Inst. Freshw. Res., Drottingholm 52 : 132-148. 